\title{
Muslim Historiography: The Trends and Nature in Perspective of India (1206-1526 A.D)
}

\author{
A. B. M. Nurul Absar \\ Lecturer in Islamic History and Culture, Centre for University Requirement Courses \\ International Islamic University Chittagong \\ Email: nurul.absar26@yahoo.com, Cell no: 0088-01818736333
}

Doi:10.5901/ajis.2014.v3n1p451

\begin{abstract}
History is considered as an account of the past and present of human race. That means authentic and scientific analysis of all activities of men included in History. Muslims have glorious contributions on the development of the science and knowledge under the Umayyad (662-750 A.D) and Abbasids (750-1258 A.D) especially on the development of Historiography. Muslims start their historiographical activities by writings on the life and activities of their last Prophet Muhammad (SAAS).Later, in the last decades of 8th century; Muslims develop these activities as a complete part of knowledge. In this way, the trends of the Muslim historiography are expanded to Persia and Indo-Pak sub-continent. In this paper, I am going to make an account on the trends and nature of the Muslim historiography of Sultanate period in India from 1206 to 1526 A.D.
\end{abstract}

Keywords: Historiography, India, Sultanate, Muslims, History.

\section{Introduction}

Historiography is known as IIm-al-tarikh in Arabic. As a responsible to the society, the account of all activities of human race is called history. ${ }^{1}$ (Yakub Ali, A.K.M, Dhaka, 2001, Tarafdar, Momtajur Rahman, Dhaka-1969) Historians are always active with the collection of historical data, compilation of books, analysis of historical events, examine authenticity of the sources of history with his wide attitude noted that he is also a member of the society. A historian cannot deny his time, place and environment, own thinking, sense of morality in his writings.( khallikan,lbn, Egypt,1299 A.H) In fact, history is itself changing because of having many obstacles. But men always want to know actual events related to the human life. From the ancient time, this trend of the knowledge continued and in this way historiography is formed as an important part of knowledge and education. ${ }^{2}$ Considering that, medieval Indian historiography is mostly with the discussion of the Muslim history because of that I would like to give a brief on the origin and evolution of the Muslim historiography of sultanate period (1206-1526 A.D) in India.

\section{What is Historiography?}

Historiography is the study of history and methodology of the discipline of history, the methods of historical research and presentation. Researchers of history collect all data and documents by his continuous research and analytical methods. Then, they prove its authenticity by their proper observations. They also re-arrange the Historical events by the course of time. By threading all these stages successfully, history becomes a scientific and authentic source of the knowledge. In this way, all kinds of writings, reading and teaching on history, analysis of the historical documents, verification of historical data, reviewing all kinds of analytical methods regarding history, confirmation of the authenticity of all historical events, discussed facts on history, composed books of history and criticism on historical matters are called Historiography. The term historiography also denotes a body of historical work on a specialized topic. Academically historiography grows up as a part of knowledge in ancient Greece by Herodotus'. ${ }^{3}$ (Ahmed, Asraf Uddin, Dhaka, 1981

${ }^{1}$-From Greek word "Historia". History means a usually chronological record of events, as of the life or development of a people or institution, often including an explanation of or commentary on those events.

2 - for details see- Yakub Ali, A.K.M.,Arab jatir Itihashchorcha, Dhaka, 2001, page-14

3 - Among the Greek historian 'Herodotus' wrote his first historical book named The Persian wars after a long visit to Italy, Athens, Sicily, Egypt, Babylon, Persia, Threes, Susa and other cities in $480-484$ B.C. He is the pioneer of history writings. 
A.D, Azizul Haq, Muhammad, Dhaka-2000 A.D) later on it becomes a regular part of research. It's also enriched by the various civilizations and enlarged to the different countries of the world, especially by the Romans and Persians historiography developed in large. ${ }^{4}$

\section{Muslim Historiography}

In the early stage of Islam, (in the beginning of $9^{\text {th }}$ century) Muslim scholars and historians considered historiography to be the third source of knowledge after the research of Quran and Sunnah. For this reason, after the collection and compilation of the Hadith of the prophet (SAAS), they start writing of the history. It seems very interesting to me that the same tradition was followed to the collection, compilation and preservation of the Hadith of the prophet (SAAS) and the history of the primary age of Islam. This tradition was followed till hijra $3^{\text {rd }}$ century (9th and10th C.E). Since third A.H Arab historiography was mostly around with the description of the events and religious theme. In course of time it was enlarged and enriched with the research of tribal, regional and national history. Also by the description of the world history, Arab historiography becomes a major part of the world historiography and it starts the glorious steps of the Muslims in the development of knowledge Standing on this, Arab historiography took its multi-formation not only discussion of the historical events but also fixed its relation to the cause and effects along with deeply analyzed criticism attached with the history. In this way historiography was developed by the Muslim scholars at the same time Arabic language was also developed because the state language was Arabic at that time and research work on historiography was continued naturally in Arabic.

In 1258 A.D, having destroyed Abbassids khilafat and Ilkhani dynasty ${ }^{5}$ was established. With the Ilkhani dynasty, 'Persi' language became the state language and it was developed during the time of Timurids ${ }^{6}$ and Safavids. ${ }^{7}$ In this way, 'Persi' entered in Indian sub-continent by the change of political power around the world (Gibbs, H.A.R, Studies on the civilization of Islam, London, 1962,). When Turkish replaced Persians, historiography was also started in Turkish language. But, the research of historiography in Turkish language has not so far enriched. (Yakub Ali, A.K.M., Dhaka2001) Turkish sultans also patronized the Persian language later and at that time, regional and dynastic history continued in Persian language. (Ibid, page-22)

Though the Arab historiography follows the Persian trends in the research of historiography, there is something different in the Arab historiography. Main theme of the Persian historiography was the conduct occupation of the kings. In the Persian history, general people was totally absent or a little bit was seen in their historiography during Illkhani period composed in Persian language "Jami-at-Tawarikh" by Rashid-ud-din. In this book, the author tries to follow the trends of At- Tabari's writings but in his writings, the character of Arab historiography is totally absent in this write up. But, Rawatas-Safa composed by Mirkhand represents Arab trends and nature. During the Timurids period, the same trends 'Tarikhi-Khani' and 'Jafarnama' were composed. In these two books, Timurids dynastic history was arranged superbly. (Yakub Ali,A.K.M, Dhaka 2002 A.D) it is said that Muslim historiography was influenced later by the trends of Arab and Persian historiography. The Persian and Turkish carried on the central Asian trends of historiography towards Indian subcontinent.

\footnotetext{
4 - Greek historians Thukudidis was considered as a pioneer of authentic history writings for applying authentic method in the writing of history. His writing is more authentic more than the writings of Herodotus. In that time historical research also started in Persia. Most of the historical writings based on the description of the fiction-fable, rumors and traditional story of their kings.

5 - Ilkhani dynasty was established in the 13th century and was based primarily in Persia as well as neighboriong territories, such as present day Azerbaijan, and the central and eastern parts of present Turky. The Ilkhanate was founded by Genghis Khan's grandson, Halagu Khan. Later time the state of Ilkhanate was expanded into territories which today comprise most of Iran, Turkmenistan, Armenia, Azerbaijan, Georgia, Turkey, western Afghanistan and southwestern Pakistan. The Ilkhanate embraced many religions, but was particularly sympathetic to Buddhism and Christianity. Later Ilkhanate rulars, beginning with Ghazan Khan in 1295 A.D, embraced Islam. 6. The Timurid dynasty was a Central Asian Muslim dynasty of Turco-Mongol linage which ruled over the whole Iran, modern Afghanistan, modern Central Asia, also large parts of contemporary Pakistan, Mesopotamia, Anatolia and the Caucasus. It was founded by the militant Timur in the 14th century.

7 - The Safavid dynasty was one of the most significant ruling dynasties of Iran. The Safavids ruled from 1501 A.D to 1722 A.D. For details see- Bernard Lewis, The Cambridge History of Islam, Cambridge University Press, 1977. P-394 


\section{Historiography in India (1206-1526 A.D)}

Muij-ud-din Muhammad bin saam permanently established Muslim rule in India after a great victory in the battle of Taarain at 1192 A.D.(Shahnewaj, A.K.M., Dhaka-2002 A.D.) During the Sultanate period (from 1206 A.D to 1526 A.D) historical research that means historiography started under the supervision and patronization of the Muslim ruler and sultan.(Sarkar, Jogodish Narayan, Kolkata, 1977) In the ancient time, there was no national history of India. In absence of historical written books from the ancient time to $11^{\text {th }}$ century; proved that before Muslim rule, no step is taken to research on history in India.(Hossain, Delwar , Dhaka,1981) it is said that, 'Torongini'8 composed by Kalhan in twelfth century is the evidence of the historical write ups before the Muslim rule in India. But, it is unbelievable that with the victory of the Muslims in India, all historical documents were destroyed. Generally, it may be happened regarding some events but it's not true that only historical data was destroyed during the Muslim conquest in India (Hossain , Delwar Dhaka,1981). If the Muslim rulers of India led to destroy all achievements, historical documents of the previous time, it would not be possible for them to contribute largely in the history of India by establishing libraries, research institute and a huge collection of books and other development in India.

\section{Trends and Nature of Historiography in India}

In the ancient India, there were no fixed and specific methods that were followed regarding the preservation and compilation of the historical events. Moreover, it was preserved through oral system. This system helps preserve religious rules and regulations, restrictions and others social rules. But it is not sufficient or enough to establish a permanent system of the preservation of all historical data and events especially the events related to the dynastic rule of India. Because, by the end of a dynasty, all glorious achievements and contributions of that dynasty were also going to end. (Yakub Ali, A.K.M.,Arab jatir Itihashchorcha, Dhaka, 2001, page-12)At that time, the scope of the historical analysis was also very limited. So, we can say that, before the Muslim rule in India, historiography was totally absent. During Muslim rule in India, historians wrote analysis and criticism of political parties, rulers, government, administration and other organs of the country and Indian historiography, on the basis of research methodology, authenticity and inquisitiveness could not reach to the similar position with the western. In fact, there are separate attitudes and thoughts among the two parts of the historians of east and west. (Yakub Ali,A.K.M, Borendro Oncholer Muslim Itihash o Oithijjo, Dhaka 2002 A.D, page-122.) For the first time, Muslim historians started their historical research by removing this difference between the East and the West. In the composition of" Tabakat- e- Firojsahi", "Tabakat-e -Akbari" Muslim historians follows the modern methods and systems. Based on this, we can say that the Muslim historians were well versed of the modern historiography elements and sources. (Yakub Ali,A.K.M, Muslim mudra o hosto likhon silpho, Dhaka, 2001, page-191).In the Sultanate period, (1206-1526 A.D) their royal court was filled up with the presence of Historians, Writers, Philosophers, Thinkers, Politicians, Orators, Poets and other scholars of the time. In this time, Indian historians did not fully follow Arabs and Persians, but they introduced a new trend in their research in accordance with Indian local perspective and reality of the time. In all regional historiographical write ups, we see this tradition was followed seriously.

Muslim conquerors conveyed the traditional historiography and cultural heritage of Arab, Turkish and Persian towards Indian sub continent. The Indian Muslim historian's writings were almost similar with the writings of the outside of India by the Muslim writers on the basis of the planning through objectives of the events and also in the decoration of language. (Sarkar, Jogodish Narayan, History of history writings in Medieval India, Kolkata, 1977, page-33.) For this reason, the culture of Hindu and their social life are rare in the write ups of the Muslim historians of India.( Hossain , Delwar Itihashtotto,(Historiography), Dhaka,1981, page-249).The reflection of the conservative mentality and social attitude was inactive in the Muslim historiography of India.Hasan Nizami is one of the famous writers among the historians of early Sultanat period. In his "Taj-ul-Maa'sir", history from 1st 'war of Tarain' of 1191 A.D to the of Sultan Iltutmish's time till 1229 A.D was placed. (M Delwar hossain, Ibid, page-250). Hasan Nizami presents some pictures of the society and culture with the political history of that mentioned period in his book. (M Delwar hossain, Ibid, page-251).In this book he discussed the various types of war weapon, musical instruments, ornaments, dresses and other household managements of that time. This discussion reflected the society and culture of the people of India during the early sultanate period.( Sarkar, Jogodish Narayan, History of history writings in Medieval India, Kolkata, 1977, page-35). This book is so important in bringing forward the history of establishment of the Muslim rule in India and social life of the Indian 
people of that time. It is an authentic book regarding the Muslim history of India.

Historian Minhaj-e-Siraj(1189-1260 A.D) composed his renowned book Tabakat-e-Nasiri. For the first time, he came to Sind from 'Ghur' of central Asia and later, he was patronized by Mamluk Sultan Sams-ud-din Ittutmish in Delhi.( M Delwar hossain, Ibid, page-252.) He also held various royal post during the period of Sultana Razia, Bahram Sah, Nasir-ud-din Mahmud and Sultan Gias-ud-din Balbon of Delhi. He also served as a principle of 'Delhi Nasiria collage' and kazi of Sultan Iltutmish of Delhi.( M Delwar hossain, Ibid, page-251.) Minhaj-e-Siraj dedicated this historical book in the name of Sultan Nasir-ud-din Mahmud. (M Delwar hossain, Ibid, page-251.) This book gave clear and authentic information on the establishment of the sultanate period of Delhi and its stability. But, it is said that he ignored or hidden weak points of the Delhi sultans because of their favor to him.( Khalik Ahmed Nijami, History and historians of medieval India, New Delhi, 1983, page- 55.) The sources of his historical data were so authentic and in somewhere he précised in description of the historical events.( Khalik Ahmed Nijami,Ibid, page no-56) In this book, social and religious information of that period was totally absent. Here, the writer only placed military expeditions and conquest of various countries. The method of this book was also conservative and it is probed that, social and religious attitude of the Delhi sultans was fully reflected in the writings of Minhaj-e-Siraj.

In India, the write-ups of Islamic history started traditionally by following the trends of other Muslim writers, but some historians ameliorated it later. Amir khosru (1253-1325 A.D) was a prominent figure among of them. He was famous in India as a Poet, Litterateur, Musician and Historian. He composed near about 100 books on various topics in his life.( Khalik Ahmed Nijami,Ibid, page- 57.) In his long life, he continued his research activities by the patronization of sultan Kaikobad, Bugara Khan, Jalal-ud-din Khalji, Ala-ud-din Khalji, Kutub-ud-din Mubarak sah Khalji and sultat Gias-uddin Tughlak. He did not write any chronological history; just he compiled some selective events of history. His six books are following: a) Kiran-as-Sadain, b) Miftah-al-Futuh, c) Khajain-al-Futuh, d) Dual rani khijir kha, e) Nuh sifihor, f) Tughlaknama. All these books are the compilation of important events of that time.

Historian Amir khosru described the dramatic and emotional meet of Sultan Kaikobad of Delhi with his father Bengal sultan Nasir-ud-din Mahmud Bugara khan and also he gave a clear picture of the city life of Delhi in his book 'Kiran-as-Sadain'. In Miftah-al-Futuh, he describes four military expeditions and victory of sultan Ala-ud-din khalji. In Khajain-al-futuh, he discussed the victory of sultan Ala-ud-din khalji. His another book, Dual rani khijir kha, was composed with the romantic description of the romance of sultan Khijir khan, son of sultan Ala-ud-din khalji with princes Dual rani daughter of king Koron of Nahrawala. His book, Nuh Sifihor, was composed by the description of the events related with sultan Kutub-ud-din Mubarak sah and in this book, the writer also presented a brief discussion on language, eco-geographical condition and royal court of Delhi sultanate. In his book, Tughlaknama, he described the victory of sultan Gias-ud-din Tughlak, especially the victorious events of Delhi in 1320 A.D.( Minhaj-e-Siraj, Tabakat-e-Nasiri, translated and edited by Abul kalam Mohammad Jakaria, Dhaka, 1983, page-245.) He wrote eventual history based on political theme and his writings also did not follow any chronological time line and period.

The motive of Amir khosru's writings was to maintain the request of the sultans and the royal members of Delhi sultanate to won prizes from royal kings and to be famous in his life as a scholer.( Tabakat-e-Nasiri, Ibid, page- 246.) In his writings, he just tried to give pleasure to the readers of history by making an interesting description and did not try to deeply analyze the historical events and purify its authenticity or he did not try to convey any kind of message in his writeups.

Futuh-us-Salatin was composed by Khaja Abdul Malik Isami. In this book, the writer described the history of around three hundred and fifty years from Sultan Mahmud of Gazni till sultan Muhammad bin Tughlak of Delhi.( Jogodish Narayan Sarkar, Ibid, page-33;Tabakat-e-Nasiri, Ibid, page-246.) Isami composed this book by the patronization of Bahmani ruler Ala-ud-din hasan sah of Deccan.( MD.Golam Rosul, The origin and development of Muslim historiography, Dhaka, 1948, page-62-63.)In this book, he strictly criticized sultan Muhammad bin Tughlak of Delhi.( A.B.M. Habibullah, The foundation of Muslim rule in India, Alahabad,1969, page-9.) But, this book of Isami was an excellent historical document to know successive history from sultan Mahmud of Gazni to sultan Muhammad bin Tughlak of Delhi.

Jia-ud-din barani was another prominent figure in Indian historiography. In his book, Tarikh-e-firojsahi, he wrote history of the period of nine Delhi sultans from sultan Balban to sultan Firoj sah Tughlok. In this book, besides political events, the writer combined the description of social, cultural and religious history of that time. He completed this book by the patronization of sultan Firoj sah Tughlok of Delhi at 1357 A.D and dedicated it to sultan Firoj sah Tughlok. (Sams-eSiraj Afif, Tarikh-e-Firojsahi, Elliot and Dowson; third volume, page-13) In his view, a historian must be impartial, truthful and out of emotion in his writings. He also believed that if writings of incompetent and lower class writers includes as history, history will lose its importance and values.( Tarikh-e-Firojsahi, Ibid, page-17) Jia-ud-din barani is considered to be the first scientific history writer among the Indian historians. 
Sams siraj Afif described the history of the period of sultan Firoj sah Tughlok in his book Tarikh-e-firojsahi. He placed Sultan Firoj Shah Tughlak as the greatest ruler of Delhi. He analyzed all steps of Sultan Firoj in perspective of religious view and praised his all activities. Afif considered Sultan Firoj Shah Tughlok as a seal among the Delhi sultans like Prophet Muhammad (SAAS) is the seal among all the Prophets of Allah (SWT). (Elliot and Dowson; third volume, page-4) So, Tarikh-e-Firojsahi is considered as a 'Manakir' book of sultan Firoj Shah Tughlak.

Yahya bin Ahmad Sirhindi includes the successive history of Muslim rule in India from the period of Muhammad bin Sum (Muhammad Ghuri) to his own period that means from 1192 A.D to 1434 A.D.( Yahya bin Ahmad bin Sorhindi, Tarikh-e-Mobaraksahi, 1932, page-9.)

This book is merely a source to know the history of Syyed Dynasty of India. Sirhindi considered history as the activities of human being.

\section{Conclusion}

Based on above mentioned discussion, it is to be noted that in Indian sub-continent, Muslim historians write the praiseworthy history under the patronization and supervision of the Muslim sultans even they named their books by the name of sultans. Historiography of this time is almost based on politics. Other side and sector of human society was totally absent in their writings. We see that some historians hardly include the description of society and culture in their writings. So, we come to an end that historiography of sultanate period was based on rulers' and the activities of the royal court and royal persons and Persian-Turkish trends were also reflected through their write-ups.

\section{References}

Ahmed, Asraf Udddin, 'ttihaser jonok Herodotus'( Herodotus:Father of the History) published by "ltihash"-Bangladesh Itihash porishod potrika, vol-8, Issue-1, Dhaka-1981, page-5

Aziz, Abdul al Duri, Nas-at al IIm al-Tarikh, Bairut, 1960, page-55-56.

Azizul Haq, Muhammad, Allama Jarir Tabari: Itihash chorchay tar obodan,(Allama Jarir and his contributions in Historiography) Dhaka 2000 A.D,page-50.

Edward Balfour The Encyclopaedia Asiatica, Comprising North India, Eastern and Southern Asia, Cosmo Publications 1976, S. 460, S. 488, S. 897

Golam Rosul, Md., The origin and development of Muslim historiography, Dhaka, 1948, page-62-63.

Gibbs, H.A.R, Studies on the civilization of Islam, London, 1962, page-119.

Habibullah, A.B.M., The foundation of Muslim rule in India, Alahabad,1969, page-9.

Hossain , Delwar, Itihashtotto,(Historiography), Dhaka,1981, page-249

M Delwar hossain, Ibid.

M Delwar hossain, Ibid.

M Delwar hossain, Ibid, page-252.

M Delwar hossain, Ibid, page-258.

M Delwar hossain, Ibid, page-259;

Ibn khallikan, Wafat -al-aian, 1st volume, Egypt,1299 A.H, page-420-421.

Khalik Ahmed Nijami, History and historians of medieval India, New Delhi, 1983, page- 55.

Jogodish Narayan Sarkar, Ibid, page-33

Jogodish Narayan Sarkar, Ibid, page-35.

Khalik Ahmed Nizami, Op. cit., page-125.

Mofijullah kabir , Muslim sovvotar sornojug, Dhaka,2001,page-178.

Minhaj-e-Siraj, Tabakat-e-Nasiri, translated and edited by Abul kalam Mohammad Jakaria, Dhaka, 1983, page-245.

MD.Golam Rosul, Ibid, page-82.

Nijami, Ibid, pae-107.

Sahjewaj, A.K.M., Varot upomohadesher Itihash Moddo jug Sultani porbo, (History of the Indian sub continent, Middle age, Sultanate period), Dhaka, 2002 A.D. p-51

Sarkar, Jogodish Narayan, History of history writings in Medieval India, Kolkata, 1977, page-33.

Sams-e-Siraj Afif, Tarikh-e-Firojsahi, (Elliot and Dowson; third volume), page-4.

Tarafdar, Momtajur Rahman, Itihaser Dorshon, Dhaka, 1969, page-1-2.

Tabakat-e-Nasiri, Ibid, page- 246.

Tarikh-e-Firojsahi, Ibid, page-17.

Tarikh-e-Firojsahi, Ibid, page-13.

The Columbia Encyclopedia (Sixth ed.). New York City: Columbia University. Retrieved 2006-11-08.

The Cambridge History of Islam, Cambridge University Press, 1977. p. 394: 
Yakub Ali, A.K.M.,Arab jatir Itihashchorcha, Dhaka, 2001, page-Introduction:7

Yakub Ali, A.K.M., Arab jatir Itihashchorcha, Ibid, page-14

Yakub Ali, A.K.M., Arab jatir Itihashchorcha, Ibid, page-Introduction:8;

Yakub Ali,A.K.M, Borendro Oncholer Muslim Itihash o Oithijo, Dhaka 2002 A.D, page-119-120.

Borendro Oncholeer Muslim Itihash o Oithijjo,Ibid, page- 126.

Yakub Ali, A.K.M., Arab jatir Itihashchorcha, Ibid, page-12.

Yakub Ali, A.K.M.,Arab jatir Itihashchorcha, Ibid, page-12.

Yakub Ali, A.K.M.,Arab jatir Itihashchorcha, Ibid, page-12.

Yakub Ali, A.K.M. Borendro Oncholeer Muslim Itihash o Oithijjo,Ibid, page- 122.

Yakub Ali,A.K.M, Muslim mudra o hosto likhon silpho, Dhaka, 2001, page-191;

Yahya bin Ahmad bin Sorhindi, Tarikh-e-Mobaraksahi, 1932, page-9. 